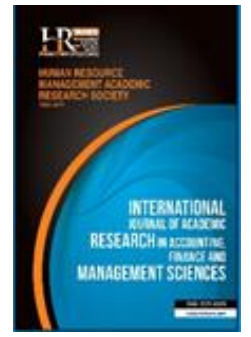

International Journal of Academic Research in Accounting, Finance and Management Sciences

Vol. 8, No.2, April 2018, pp. 28-36

E-ISSN: 2225-8329, P-ISSN: 2308-0337

(C) 2018 HRMARS

www.hrmars.com

To cite this article: Anghel, M.-G., Mirea, M., Badiu, A. (2018). Analysis of the Main Aspects Regarding the Price Indices Applied in the Determination of Inflation, International Journal of Academic Research in Accounting Finance and Management Sciences 8 (2): 28-36.

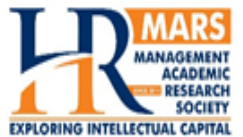

http://dx.doi.org/10.6007/IJARAFMS/v8-i2/4135 (DOI: 10.6007/IJARAFMS/v8-i2/4135)

\title{
Analysis of the Main Aspects Regarding the Price Indices Applied in the Determination of Inflation
}

\author{
Mădălina-Gabriela ANGHEL ${ }^{1}$, Maria MIREA ${ }^{2}$, Alexandru BADIU ${ }^{3}$ \\ ${ }_{1}^{1}$,Artifex" University of Bucharest, Romania, ${ }^{1}$ E-mail: madalinagabriela anghel@yahoo.com \\ ${ }^{2,3}$ Bucharest University of Economic Studies, Romania, \\ ${ }^{2}$ E-mail: mirea maria@yahoo.com, ${ }^{3}$ E-mail: badiu@transferrapid.com
}

\begin{abstract}
Inflation is the abridged or statistically synthesized form of price rises. Inflation can be expressed in the terms we commonly encounter in analyzes and daily studies as the consumer price index, which is nothing more than the evolution of the prices of the goods bought and of the tariffs and services used. It is, to put it this way, the main index or instrument for assessing inflation. However, a number of other indicators that are specific to the economic activity domains are used in the calculation of the consumer price index. Thus, we find the index of industrial production prices, the unit value of exports and imports, the cost of living index, the retail price index, the construction cost index, the agrifood product price index, or the average exchange rate index. All of these indicators that we have mentioned are used in inflation calculations in the sense that they are being discussed when it comes to determining how inflation is evolving. Inflation is an indicator that has negative effects on the real outcomes of economic activity and negatively influences the real value of the incomes of the population at one time. In calculating inflation, a number of issues have to be resolved, such as the definition of the calculated indicators, the advantages and disadvantages of the harmonization of the indicators mentioned the scope of each of them, the data sources and especially the most commonly encountered problem, the weighting system which we use. We know that there is an integrated household survey, family budget surveys, so that the data obtained can be processed so that they can present in a realistic way the evolution of prices within the national economy. Inflation is also important because once we know the concrete results; we can bring macroeconomic performance indicators as well as other sizes at a real comparability level. It is known that in the evolution of each period of time the macroeconomic indicators are calculated in the prices of the respective period, and then by deflation we manage to bring the indicators to a level of comparability. In the study, the emphasis is on solving these issues, so that specific inflation indices, such as the monthly inflation rate, the monthly average inflation rate, the inflation rate at the end of the period or year or the annual inflation rate, will be harmonize, correlate and put in place the possibility of making a realistic inflation calculation in the national economy. The Laspeyres or Paasche type weighting issue involves two issues that need to be considered when we build indicators that measure inflation.
\end{abstract}

Key words

Price Index, Inflation, Harmonized Inflation Index, Tariff, Deflation, Comparability

Received: 25 Apr $2018 \quad$ C The Authors 2018

Revised: 30 Apr 2018 Published by Human Resource Management Academic Research Society (www.hrmars.com)

Accepted: 05 May 2018 This article is published under the Creative Commons Attribution (CC BY 4.0) license. Anyone may reproduce, distribute, translate and create derivative works of this article (for both commercial and noncommercial purposes), subject to full attribution to the original publication and authors. The full terms of this license may be seen at: http://creativecommons.org/licences/by/4.0/legalcode

\section{Introduction}

In the present paper, the authors start from the conclusions they have drawn from the theoretical study with practical references in relation to the characterization of inflation by its concrete definition, then by establishing the methodology for calculating the main indicators to be considered. Also, the consumer price index and the harmonized inflation index are briefly presented, comparing the two indices with the 
statement that the first is more a synthetic index, which we commonly call inflation, but the harmonized index of inflation is the one a more comprehensive indicator that includes changes across the national economy, by industry, goods and services. The indicators used to measure prices in industry, agriculture, construction or service tariffs are all presented in order to provide a complete overview of the inflation rate, annual rate, average rate, and so on. Here are some examples to understand how these indicators are calculated and based on the value of these indicators, to make a concrete and accurate assessment of price developments in the national economy in a double sense. On the one hand, to show the possibility of deflating the macroeconomic results indicators in order to bring it to comparability level and on the other hand to give the real level of purchasing power parity of the national currency within a given time period . There is also a series of opinions on the methodological aspects to be considered in the organization of household surveys or family surveys in order to be able to collect prices correctly on the basis of a selection that would lead to the formation of a representative sample. The issue of prices used in inflation analysis is essential and should therefore be known and used when such analyzes are made. Successively there are presented the peculiarities of price calculation in each field of activity, how they evolve in the market economy.

\section{Literature review}

Anghel et al. (2016) presented a series of elements regarding the evolution and effects of inflation in Romania. Anghelache et al. (2017) highlighted the statistical methods of weighting the indicators, usually by the consumer price index, to show how they were calculated and then transformed into real prices to ensure comparability. Anghelache et al. (2013) is a reference work in the field of macroeconomic statistics. analyzed and presented the main ways to measure inflation. Armantier et al. (2015) conducted an experiment in which they analyzed consumer expectations for inflation. Aruoba and Diebold (2010) focused on monitoring real-time macroeconomic activity on the interaction of inflation with real activity. Clark and Doh (2011) used Bayesian methods to explain the uncertainty surrounding the trend inflation model to obtain an alternative estimate of trend inflation and to generate average forecasts of medium-term inflation forecasts. Cogley and Sbordone (2008) showed that persistence of inflation stems mainly from the change in the long-term inflation component, attributable to changes in monetary policy. Fuhrer (2012) analyzed alternatives to the assumption of rational expectations in the applied macroeconomics and examined the role of expectations in the inflation process. Fuster et al. (2010) presented issues related to natural expectations and macroeconomic fluctuations. Hornstein and Wolman (2005) investigated the impact of nonzero average inflation on an alternative model of nominal rigidities. Kim and Henderson (2005) demonstrated that the nominal targeting of revenue growth dominates inflation targeting for plausible parameter values. Malmendier and Nagel (2016) conducted a study demonstrating differences in life experiences, strongly reflecting differences in subjective inflation expectations, including household lending and lending behavior, or the choice of fixed investments versus floating-rate variables and mortgages. Mishkin (2007) presented the main aspects of changes in inflation dynamics, monetary policy implications and inflation forecasts. Nunes (2010) estimated the Phillips curve that allows a simultaneous role of rational expectations and studies. Söderlind (2011) showed that equilibrium inflation may shift in response to changes in inflation risk premiums and liquidity premiums, as well as to expected inflation fluctuations. Trehan (2015) addressed a number of issues related to the projected inflation forecasts.

\section{Research methodology and data. Results and discussions}

The economic indicators expressed in money are obtained and expressed in current prices, also called nominal indicators. For time comparisons it is necessary to deduce the contribution of the factors, the influence of the changes in the physical volume, respectively in the prices, to obtain the indicators in the "real" expression. Deflation indicators, as a measure of inflation, are price indices, different forms of calculation and content. Conceptually, inflation is the expression of a macroeconomic imbalance of a monetary-material nature, and is mainly perceived by the population as a general and sustained increase in prices.

"Imposed" or "controlled" prices have not been long-term safe against inflation; this practice has been particularly marked in the command economy. 
Inflation can be determined by excess of money issuance - currency inflation, excess solvency demand - demand inflation, excess nominal demand - credit inflation, excess in costs - inflation through costs, more often due to insufficient production - supply inflation. In statistics it is a question of finding a measure of the level of inflation through indicators of good accuracy, obtained in a shorter time period and with minimal expenses.

Specialists appreciate the level of inflation expressed as annual percentage rate as follows: subnormal inflation (0 to 3\%); normal (between 3 and 5\%); moderate (between 5 and 10\%); maintained (10 and 20\%); persistent (between 20 and 100\%); energetic (between 100 and 200\%); accelerated (between 200 and 300\%); excessive (over 300\%).

The price indices are most frequently used to measure inflation.

The construction of these price indices is based on some deviations from the "classical methodology", where the synthetic price index is obtained as the harmonic mean of the individual price indices, mainly because of the difficulty of obtaining the necessary information in a timely manner and at a cost reasonable.

The most used statistical indices in inflation measurement are:

- The Consumer Goods Price Index (IPBC) measures the overall evolution of purchases of goods and services prices used by the population;

- The Industrial Production Price Index (IPPI) expresses the evolution or average price changes of the products manufactured and delivered by the domestic producers actually practiced at the first stage of their marketing. It is used both to deflate industrial production valued at current prices and to determine inflation in the wholesale price sphere;

- The Export/Import Unit Value Index (IVU) characterizes the dynamics of export/import contract prices, the expansion of the fluctuation of commodity prices considered representative and allows deflagration through it of the indicators that characterize the external exchanges and even the calculation of the "exchange ratio";

- The cost-of-living index (ICV) measures the cost at market prices in the current period to maintain the standard of living reached in the base period. It is calculated as the ratio between the hypothetical cost and the actual cost of the base period. It is mainly used in determining actual salaries (revenues);

- The Retail Price Index (IPAM) expresses the change in prices for goods sold through the retail network;

- The Construction Cost Index (ICC) highlights the change in the prices of housing construction;

- The Agro-Foodstuff Price Index (IPPA) shows the evolution of agro-food products' prices on the "peasant market"; inflation.

- The evolution of the "leu/euro" or "leu/dollar" exchange rate may be used as a measure of

A private relationship exists between the consumer goods price index and the cost of living index, which can be summarized as follows: IPBC is an approximation of ICV as an instrument that estimates "consumption costs"; IPBC (Laspeyres formula) provides an upper limit for ICV (ICV <IPBC); IPBC and ICV measure cost changes, not the change in revenue needed to maintain the standard of living.

- The cost-of-living ratio calculation in advanced economies based on the Paasche formula is used to verify or counter the weighting coefficients of the base period during the current period, the formula used is:

$$
I^{I C V}=\frac{\sum v_{1}}{\sum \frac{1}{i^{p}} v_{1}},
$$

Where:

$\mathrm{v}_{1}=$ sales during baseline period;

$\mathrm{i}^{\mathrm{p}}=$ individual price indices.

IPBC and ICV are not affected by changes in income taxes, but include sales taxes through actual price and other indirect taxes. 
- Consumer Goods Price Index (IPBC)

Until 1990, the consumer price index was calculated as a Paasche type index, thus as a weighted harmonic average of individual price indices. The weights used were production values in current prices. This was possible due to the controlled way of the evolution of prices in the economy (an authority - the State Committee of Prices functioned), but also the possibility of tracking the full volume of sales from the state trade through the "Reporting System". For the prices on the "unorganized market", the agro-food market, records were organized, but the prices imposed by the mercurial, not the actual ones, were recorded.

After 1990 (the price liberalization action started in the reform process since November 1), this method could no longer be applied, both because of changes in the ownership structure of trade and as a consequence in changing the way data is being collected, as well as the diversification of prices in the outlets. It went to the system of sampling, system applied in market economy countries. The National Institute of Statistics proceeded to apply the Eurostat methodology, with some particularities for the possibilities of data collection from us. In December 1990 the first IPBC was published with data for November and the evolution compared to October. The IPBC data for March 2018, with reference period February 2018, are shown in table 1.

Table 1. Price indices in 2018, March/February

\begin{tabular}{|c|c|}
\hline $\begin{array}{c}\text { Consumer Goods Price Indices } \\
\text { (IPBC) }\end{array}$ & $\begin{array}{c}\text { Percentages } \\
\text { (November/October) }\end{array}$ \\
\hline Food goods & 100,48 \\
\hline Non-food goods & 100,15 \\
\hline Services & 100,30 \\
\hline
\end{tabular}

The characterization of the methodology for the consumer goods price index has as main elements: the definition, the advantages and disadvantages of the use, the scope of coverage, the data sources, the samples used in the construction, the weighting system, the actual calculation, the inflation calculated as IPBC rhythm, inflation, uses of the CPI and the purchasing power of the national currency.

IPBC is the statistical tool that measures the overall evolution of prices of purchased goods and service tariffs used by the population over a given period (current) over a previous (base) period. Frequently, IPBC is also called the general price index.

The consumer price index has as its main advantages the better promptitude than that of the "GDP deflator" and the broader sphere of coverage compared to IPPI, and as disadvantages the lower coverage and the relatively lower accuracy, both against the "GDP deflator".

The scope covers only the items that come into direct consumption, excluding self-consumption or consumption from own resources, investment and accumulation expenses, interest on credits, fines, taxes and labor costs for agricultural production of individual households according to the annual methodology calculations published by the National Institute of Statistics (INS) in the "Statistical Bulletin".

Data sources are formed by recording the prices and tariffs practiced by commercial units or service providers through a survey conducted by the NIS. The collection of data, provided by statistically specialized personnel, is carried out on the basis of questionnaires corresponding to the groups of goods (food, non-food) and services. Statistical surveys on consumer prices use the sample of localities, established in compliance with the representativeness restrictions based on the number of inhabitants and the volume of sales of goods and services. It includes a number of urban localities from which research centers are selected. The sample of observation units includes shops and service units to the population of research centers. The survey is based on ensuring representativeness from the point of view of the volume of sales of goods and the provision of services.

The units in which prices/tariffs are recorded are kept in the sample, as long as possible, for a longer period to ensure the continuity and comparability over time of the data series. Single country prices/tariffs set out in normative acts or negotiation notes (electricity and heat, methane gas, rail, air, river, postal and courier services, radio-TV subscriptions) are recorded on the basis of official information. The sample of goods and services includes assortments have a significant share in population consumption. The nomenclature used is structured on three levels of aggregation: groups, posts and assortments: 
Assortments are individualized in the field through varieties of goods and services.

The information gathered through this research is complemented by the research on the prices of the main agricultural products sold by private producers on the agri-food markets, thus ensuring the supply of the population.

The weights used for the calculation of consumer price indices were initially obtained through the Integrated Household Survey (AIG), and currently in the Family Budget Survey (ABF), and result from the structure of monthly average expenses incurred by a household for the purchase of goods and services necessary to meet the needs of living. Periodically, the structure of the expenditures of the population is analyzed, and when the mutations are significant, the weights are updated. Thus, starting with January 2005 , the IPBC calculation uses the weights resulting from the structure of average household expenditure in 2003.

The CPI is calculated as a Fixed Base Laspeyres index. From January 2005, the calculation of monthly fixed-rate indices will be made with the average prices in $2003(2003=100)$ and the weights of the same year determined on the basis of the average expenses in the Family Budget Survey.

In order to ensure the continuity of the series of indices constructed with different bases, a "connection coefficient" is used which allows the connection of the monthly index series of the current year with the base (100). The connection coefficient is determined as the ratio between the Laspeyres-type index calculated for the current month and the base (100). The comparison of two calculated indices in different bases is done by comparing the index to be compared in the new base multiplied by the coefficient of comparison to the comparison index computed in the old base.

The IPBC computing relation is as follows:

$$
\text { IPBC }=\frac{\sum I^{p}\left(p_{0} q_{0}\right)}{\sum\left(p_{0} q_{0}\right)},
$$

Where:

$$
\frac{\left(p_{0} q_{0}\right)}{\sum\left(p_{0} q_{0}\right)}=C_{p}
$$

and:

$I^{p}=$ price index of the specific aggregation level (for the item or group of goods and services); $C_{p}=$ specific weighting factor (post or group of goods and services).

The actual calculation of the consumer price index is, as a first step, in calculating the average price at the varietal level as a simple arithmetic mean of the average price of the three decades:

$$
\begin{aligned}
& \bar{P}_{t}=\frac{\bar{P}_{1}+\bar{P}_{2}+\bar{P}_{3}}{3}, \\
& \text { Where: } \\
& \bar{P}_{t}, \bar{P}_{1,2,3}=\text { Average monthly }(\mathrm{t}) \text { or decadal price }(1,2,3) .
\end{aligned}
$$

The individual indices of the variety are calculated as a ratio between the average price $\left(\bar{P}_{t}\right)$ and the average price for the corresponding year, from which the weighting coefficients have been extracted. The calculation relation is:

$$
i_{t / a n}^{p v}=\frac{\bar{P}_{t}}{\bar{P}_{a n}}
$$

Where:

$$
i_{t / a n}^{p v}=\text { the individual indices of the variety in month " } \mathrm{t} \text { " in relation to the year considered. }
$$


The second calculation step consists of the calculation of the average index at the assortment level as a simple geometric mean of the individual indices of the varieties in the " $n$ " observation centers:

$$
\bar{I}_{t / a n}^{p s}=\sqrt[n]{\Pi i^{p v}}
$$

Where:

$\mathrm{i} / \mathrm{an}=$ the average stock-level index in month $\mathrm{t}$ in relation to the year considered.

The third computation step is aggregated, leading to the calculation of the post, group or general level index, according to the Laspeyres index formula, of the form:

$$
I_{\text {t/an }}^{p}=\frac{\sum I_{\text {t/an }}^{p} \times\left(p_{0} q_{0}\right)}{\sum\left(p_{0} q_{0}\right)}, \quad \frac{\left(p_{0} q_{0}\right)}{\sum\left(p_{0} q_{0}\right)}=C_{p} \text {, }
$$

Where:

$I_{t / \text { an }}^{p}=$ index at post, group or general level in month $\mathrm{t}$ in relation to the year considered;

$C_{p}=$ specific weighting factor (assortment, post or group) according to the base year established by the Family Budget Survey.

In conclusion, IPBC is a synthetic or group index calculated with a weighted arithmetic mean of indices at various lower aggregation levels (group, post, assortment). The average annual inflation rate is as follows:

$$
\bar{R}_{A N t / A N(t-1)}=\frac{\overline{I P C}_{A N t}}{\overline{I P C}_{A N(t-1)}} \times 100-100
$$

Among the IPC uses, we specify real wage calculation $(\mathrm{Sr}=\mathrm{Sn} / \mathrm{IPBC} \cdot 100)$, real pension $(\mathrm{Pr}=\mathrm{Pn} / \mathrm{IPC}$. $100)$, indexation of wages and pensions, determination of real consumption, and so on.

The national currency purchasing power index (IPCMN) is the inverse of the IPC, value, indicating the loss of purchasing power of the national currency over a certain period of time, the relationship is used:

$$
\text { IPCMN }=\frac{1}{I P B C} \text {. }
$$

Where:

IPCMN = purchasing power index of the national currency;

$\mathrm{IPBC}=$ consumer goods price index.

The IPC calculation methodology in Romania is harmonized with the methodology used by the European Union Statistical Office (Eurostat) at the level of classifications, nomenclatures, sampling and calculation methods. The COICOP (Classification of Individual Consumption by Destination) classification agreed by CEE/Eurostat/OECD ensures the comparability of European indices.

Consumer price indices by commodity groups and services COICOP results from the aggregation of the assortments and items included in the nomenclature for the calculation of the consumer price index at national level in the structure and content provided in this classification.

Harmonization of price indices at European level requires the adoption and enforcement of EC Regulation no. 2494/95, calendar and harmonization rules. Consumer price indices are comparable when reflecting the differences between price variations or national consumption patterns. EC Regulation no. 1749 has established comparable scope, minimum quality adjustment rules and the IPBC calculation formula for elementary aggregates. Regulation no. 2214/1996 established the mode of transmission of statistical data.

IPBC can also be calculated as a mobile base index using the relationship: 


$$
I P C_{t / t-1}=\frac{I P C_{a n}}{I P C_{t-1 / a n}}
$$

Inflation calculated as the IPBC rhythm is a unanimously accepted solution as a means of statistical expression. When IPBC is calculated as a coefficient, the inflation rate is:

$R_{\text {inf }}=I P B C-1 ;$

and when IPBC is calculated in percentage expression, the inflation rate becomes:

$R_{\text {inf }}=I P B C-100$.

The following specific indicators are used to measure inflation:

- monthly inflation rate or price increase in a month " $\mathrm{t}$ " as against the previous month "t-1":

$$
R_{t / t-1}=I P B C_{t / t-1} \times 100-100 \text {; }
$$

- the monthly average inflation rate or the geometric mean of monthly increases for a given period, which express the average of monthly price increases:

$$
\bar{R}=(\sqrt[n]{\Pi I P B C}) \times 100-100 ;
$$

- the inflation rate at the end of the period (year) or the increase in consumer goods prices in December of this year compared to December of the previous year:

$$
R_{\text {t/december }}=I P B C_{t / \text { december }} \times 100-100
$$

- the annual inflation rate, which measures the average price increase in a year over the previous year, calculated as a ratio between the average price index of one year and the previous year, both determined as simple arithmetic averages of the monthly indices in each year, computed against the same basis (October $1990=100$ ).

- The Industrial Production Price Index (IPPI) expresses the overall evolution of prices of industrial products and services manufactured and delivered by domestic producers in a given period (current compared to an earlier basic period) at the first stage of marketing of products and services.

For the construction of the industrial production price index, only the transactions corresponding to the first stage of the marketing of the products, i.e. when leaving the producing enterprises, are taken into account.

The observed variance is the price associated with these transactions, which will be determined by the seller (the economic agent), the specificity of the product being traded, and the type of buyer and other characteristics of the transaction. The large number of transactions carried out by industrial economic agents within the national economy makes it impossible to pursue them fully. Therefore, observation and collection of selling prices of industrial products used in industrial producer price index calculation is performed on a representative sample of businesses in each CANE, based on a unique nomenclature of industrial products. The industrial production price index covers almost all the mining and processing industries as well as the energy sector. Products produced by the sampled economic operators are treated differently according to their main destinations (domestic or export).

The main nomenclatures used in the calculation of the industrial production price index are: Classification of National Economy Activities, elaborated from the necessity of reflecting the new economic relations and ensuring the alignment with the European Community Nomenclature of Activities; The product nomenclature which tracks and records the prices of the assortments manufactured and delivered by the economic operators in the sample which will be made on the basis of a unique nomenclature of industrial products. The product in the nomenclature represents the first level of aggregation of the component assortments that characterize the movement of industrial goods prices; Assortment Nomenclature is a good material resulting from a well-defined manufacturing process with specific technical-functional characteristics. The assortment represents the basic level at which the transaction 
price is traced. The range nomenclature is not unique in the country, it is carried out at the level of each economic agent by the statistician specialists together with the business specialists; The nomenclature of economic agents is the main source of data for the construction of the sample of economic agents carried out by the statistical survey "Annual Statistical Survey" in enterprises.

The construction, weighting and calculation algorithm of the industrial production price index is of the Laspeyres type using a constant weighting system for the successive aggregation of data on the value of the industrial output traded per destination.

The weighting system used in the calculation of the industrial production price index shall be established separately by destination as it is used for the calculation of the industrial output price index delivered to the domestic market or the industrial output price index delivered for export. The weights for destinations for all aggregation levels are determined from the Annual (structural) Business Survey in enterprises.

Agricultural price indices express the overall price evolution of agricultural products sold by domestic agricultural producers over a given period (commonly referred to as "current") compared to an earlier period (called base or reference). Price observation and collection of average prices and price indices shall be made on a sample basis, on representative sales channels, depending on the nature of the product, using a sample of agri-food markets, processors, wholesalers and agricultural trading companies and units research and agricultural production.

The sample of products includes the representative varieties for each product, chosen on the basis of specific characteristics: quality, variety, size, weight, age, etc. and the most common marketing conditions.

Pricing is done weekly in agri-food and lunar markets for food, processors, wholesalers and agricultural commercial companies.

Prices have the following characteristics: they reflect the first stage of marketing the products; do not include transportation, storage etc.; do not include subsidies on the product as well as VAT.

Average prices of products sold in agri-food markets at the local level are determined as a simple arithmetic mean of weekly prices. The calculation system is based on the Laspeyres variant. The weighting system for aggregate indices is based on the information obtained from the Economic Accounts in Agriculture and represents the value share of a product in the total value of agricultural production. At the level of the weighing product the information from the Statistical Survey of Plant and Animal Production is used. The Construction Cost Index is a statistical indicator that measures the evolution of the costs incurred in carrying out construction works performed over a given period compared to a reference period. The construction of the indices uses the nomenclature of construction works for the main categories of construction works and objects: new constructions; capital repairs; maintenance and repairs.

Each category of work is divided into three types of building objects, namely: residential buildings; non-residential buildings and engineering constructions. It is not included in the construction activity: capital repairs of the machinery that are included in the branch of industry, assembly of machinery and metal constructions executed by "industrial" enterprises. In the pricing survey are included units that perform the works in the enterprise. The cost index is calculated as a fixed-base Laspeyres index. The weights are represented by the specific weights of each item of expenditure versus the total. The main items of expenditure are: materials, labor, equipment, transport costs, indirect costs. On expenditure items, the Laspeyres price indices are: industrial output price index for construction materials; labor cost index in construction; Industrial Construction Price Index for Construction Machinery; industrial output price index for construction means of transport; consumer price index.

The construction cost index is calculated by aggregating the cost indices by categories of works, and for each category of works, the index is derived from the aggregation of the indices by object categories, which in turn is determined on the basis of expenditure items and price indices associated with them.

\section{Conclusions}

From the study, the authors departed a series of theoretical and practical conclusions. Firstly, there are a number of methodological issues to be considered when constructing and calculating price indices. Based on these, the price change will be calculated, in other words, the monthly, annual or average inflation rate will be calculated. Another theoretical conclusion is that only by the correct calculation of the 
indicators that measure inflation can be reached the possibility to deflate the macroeconomic indicators of results on the total as well as in the structure in order to ensure their comparability from a period of time to other. Another conclusion is that the inflation rate has a negative effect on the national economy as a whole, and therefore the factors that determine the price increase must be known and as far as possible correlated or corrected by measures to be taken. Of course, inflation has a decisive role on the real level of quality of life. Only by adjusting incomes to the level of inflation can at least ensure a constant standard of life. This is an easy theoretical problem, but in practice it requires obtaining at the macroeconomic level or at the level of each economic agent the incomes on the basis of which they can be brought to a real level, comparable to the previous periods. The authors refer in particular to income from salaries, pensions and other state aids or allowances which, because of inflation, have a lower real value, thus ensuring a lower percentage of maintaining an adequate standard of living, and when put the problem to be improved must be obtained, additional income earned. From a practical point of view, the study reveals the need to use the entire methodology to calculate inflation, or in another approach to ensure knowledge of the effects of inflation as a factor acting at micro- and macroeconomic level.

\section{References}

1. Anghel, M.G., Anghelache, C. and Manole, A. (2016). Some aspects regarding the inflation evolution during the last period. Romanian Statistical Review, Supplement, 8, 104-109.

2. Anghelache, C., Popovici, M., Solomon, A.G. and Stanciu, E. (2017). Aggregates in Real Expression and Price Indices by Deflation. International Journal of Academic Research in Business and Social Sciences, 7 (6), 1053-1060.

3. Anghelache, C., Mitruţ, C. and Voineagu, V. (2013). Statistică macroeconomică. Sistemul Conturilor Naţionale, Editura Economică, Bucureşti.

4. Anghelache, C., Voineagu, V. and Gheorghe, M. (2013). Metode și modele de măsurare şi analiză a inflaţiei, Editura Economică, Bucureşti.

5. Armantier, O., Bruine de Bruin, W., Topa, G., Klaauw, W. and Zafar, B. (2015). Inflation Expectations and Behavior: Do Survey Respondents Act on their Beliefs?. International Economic Review, 56 (2), 505-536.

6. Aruoba, S.B. \& Diebold, F.X. (2010). Real-Time Macroeconomic Monitoring: Real Activity, Inflation and Interactions. American Economic Review, 100, 20-24.

7. Clark, T.E. and Doh, T. (2011). A Bayesian evaluation of alternative models of trend inflation, Federal Reserve Bank of Cleveland in Working Paper with number 1134.

8. Cogley, T., and Sbordone A. (2008). Trend Inflation, Indexation, and Inflation Persistence in the New Keynesian Phillips Curve. American Economic Review, 98 (5), 2101-2126.

9. Fuhrer, J. (2012). The Role of Expectations in Inflation Dynamics. International Journal of Central Banking, 8 (1), 137-165.

10. Fuster, A., Laibson, D. and Mendel, B. (2010). Natural Expectations and Macroeconomic Fluctuations. Journal of Economic Perspectives, 24, 67-84.

11. Hornstein, A. and Wolman, A.L. (2005). Trend Inflation, Firm-Specific Capital, and Sticky Prices. Economic Quarterly, 91 (4), 57-83.

12. Kim, J. and Henderson, D.W. (2005). Inflation Targeting and Nominal-Income-Growth Targeting: When and Why are They Suboptimal?. Journal of Monetary Economics, 52, $1463-1495$.

13. Malmendier, U. and Nagel, S. (2016). Learning from Inflation Experiences. The Quarterly Journal of Economics, 131 (1), 53-87.

14. Mishkin, F.S. (2007). Inflation Dynamics. International Finance, 10 (3), 317-334.

15. Nunes, R. (2010). Inflation Dynamics: The Role of Expectations. Journal of Money, Credit, and Banking, 42 (6), 1161-1172.

16. Söderlind, P. (2011). Inflation risk premia and survey evidence on macroeconomic uncertainty. International Journal of Central Banking, 7 (2), 113-133.

17. Trehan, B. (2015). Survey Measures of Expected Inflation and the Inflation Process. Journal of Money, Credit and Banking, 47 (1), 207-222. 